\title{
Effect of exercise on occurrence of diurnal rhythms of plasma ions and metabolites in Thoroughbred racehorses
}

\author{
[Efeito do exercício na ocorrência de ritmos diários de ions e metabólitos plasmáticos em \\ cavalos de corrida Puro Sangue Inglês] \\ P.C.R. Viana ${ }^{1}$, M.C. Caldas-Bussiere ${ }^{1 *}$, R.S.Q.S. Marins ${ }^{1}$, L.S. Menna-Barreto ${ }^{2}$, L.J. Cury ${ }^{3}$ \\ ${ }^{1}$ Centro de Ciências e Tecnologias Agropecuárias - UENF \\ Av. Alberto Lamego, 2000 \\ 28013-602 - Campos dos Goytacazes, RJ \\ ${ }^{2}$ Instituto de Ciências Biológicas - USP - São Paulo, SP \\ ${ }^{3}$ Jockey Clube Brasileiro - Rio de Janeiro, RJ
}

\begin{abstract}
Records of plasma calcium $\left(\mathrm{Ca}^{++}\right)$, phosphorus $\left(\mathrm{P}_{\mathrm{i}}\right)$, potassium $\left(\mathrm{K}^{+}\right)$, sodium $\left(\mathrm{Na}^{+}\right)$, chloride $\left(\mathrm{Cl}^{-}\right)$, magnesium $\left(\mathrm{Mg}^{++}\right)$, iron $\left(\mathrm{Fe}^{++}\right)$, glucose, cholesterol, triglycerides and total protein levels were measured to determine the effects of exercise on occurrence of diurnal rhythms in Throughbred racehorses $(n=7)$ under physical training. Physical activities consisted of gallop on the track and walking. Blood samples were collected from jugular vein every $4 \mathrm{~h}$ over a $48 \mathrm{~h}$ period. Plasma $\mathrm{Ca}^{++}, \mathrm{K}^{+}, \mathrm{Mg}^{++}$and $\mathrm{Na}^{+}$levels were obtained by flame photometry; and, $\mathrm{P}_{\mathrm{i}}, \mathrm{Cl}^{-}, \mathrm{Fe}^{++}$, glucose, cholesterol, triglycerides and total protein levels were measured by colorimetric tests using visible UV spectrophotometry. The data were analyzed using a $24 \mathrm{~h}$ period to each exercise performed. Diurnal rhythm of Pi was observed when walking was the physical activity performed, and its acrophase occurred at the light period. Plasma triclycerides showed significant diurnal rhythms, with their acrophases occurring at the dark period, even when walking or gallop were performed. High intensity exercise (gallop) decreased triglycerides amplitude. No significant diurnal rhythms of other variables were found. Gallop, as physical activity, masked phosphorus diurnal rhythm. However, physical training did not influence triglycerides diurnal rhythm occurrence. High intensity exercise (gallop) just declined triglycerides amplitude.
\end{abstract}

Keywords: horse, chronobiology, exercise, ions, metabolites, diurnal rhythms

\section{RESUMO}

Mensuraram-se as concentrações plasmáticas de cálcio $\left(\mathrm{Ca}^{++}\right)$, fósforo $\left(\mathrm{P}_{i}\right)$, potássio $\left(\mathrm{K}^{+}\right)$, sódio $\left(\mathrm{Na}^{+}\right)$, cloreto $(\mathrm{Cl})$, magnésio $\left(\mathrm{Mg}^{++}\right)$, ferro $\left(\mathrm{Fe}^{++}\right)$, glicose, colesterol, triglicerídeos e proteínas totais para determinar os efeitos do exercício sobre a ocorrência dos ritmos diários em cavalos de corrida da raça Puro Sangue Inglês ( $n=7)$, em treinamento. A atividade fisica consistiu de galope na raia e passo. Amostras de sangue foram coletadas da veia jugular a cada $4 \mathrm{~h}$ durante um periodo de 48h. As concentrações plasmáticas de $\mathrm{Ca}^{++}, \mathrm{K}^{+}, \mathrm{Mg}^{++}$e $\mathrm{Na}^{+}$foram obtidas por espectrofotometria de absorção atômica com chama, e as concentrações de $\mathrm{P}_{i}, \mathrm{Cl}, \mathrm{Fe}^{++}$, glicose, colesterol, triglicerídeos e proteína total foram mensuradas por testes colorimétricos utilizando-se a espectrometria de luz UV visivel. Os dados foram analisados utilizando-se um periodo de 24 h para cada tipo de exercício desenvolvido. Ritmo diário de $P_{i}$ foi observado quando o passo foi a atividade fisica desenvolvida, apresentando sua acrofase no periodo diurno. A concentração plasmática de triglicerídeos mostrou significante ritmo diário com a acrofase ocorrendo no periodo noturno, independente se foi desenvolvido o galope ou passo. O exercício

Recebido em 28 de julho de 2006

Aceito em 10 de abril de 2007

*Autor para correspondência (corresponding author)

E-mail: claracal@uenf.br 
de alta intensidade (galope) diminuiu a amplitude dos triglicerídeos. Nenhum ritmo diurno foi achado nas outras variáveis. Estes resultados mostram que o galope como atividade fisica, mascara o ritmo diário do fósforo. Entretanto, o treinamento fisico não apresentou nenhum efeito na ocorrência do ritmo diário de triglicerídeos, somente na sua amplitude.

Palavras-chave: cavalo, cronobiologia, exercício, ions, metabólitos, ritmos diários

\section{INTRODUCTION}

The performance of a horse during the competition is a result of a combination of many complex interactions including: age, breed, genetic potential, strength, and fitness (Nogueira et al., 2002). Exercise physiology is a scientific endeavor, which aims the understanding of issues related to training, fitness, and athletic performance (Rose et al., 1998).

Laboratory tests are an important key in exercise physiology researches, because they can easily determine hematological responses to exercise. However, with chronobiological studies beginning, time has to be taken under consideration. So, it is better to determine exercise responses at each time of the day, in order to establish a sine wave (Cipolla-Neto, 1998).

Viana et al. (2003) reported diurnal rhythms in Thoroughbred racehorses, under physical training. However, temporal patterns of blood constituents due exercise have to be described in horses. This will help on a better comprehension of physiological events and on physical training of athlete horses (Viana et al., 2003).

The purpose of this study was to investigate the effects of exercise on occurrence of diurnal rhythms in plasma ions $\left(\mathrm{Na}^{+}, \mathrm{K}^{+}, \mathrm{Cl}^{-}, \mathrm{Ca}^{++}, \mathrm{P}_{\mathrm{i}}\right.$, $\mathrm{Fe}^{++}$, and $\mathrm{Mg}^{++}$) and metabolites (glucose, cholesterol, triglycerides, and total proteins) levels in Thoroughbred racehorses.

\section{MATERIALS AND METHODS}

The study was carried out using seven Thoroughbred racehorses (two males and five females), which were stabled and racing at the Brazilian Jockey Club, in Rio de Janeiro, RJ, during summer (January, photoperiod 05:15h 18:40h).
Physical activities consisted of gallop on the track, which was done between $05: 00 \mathrm{~h}$ and 07:00h, and walk at 16:00h. Just one type of exercise was daily done (gallop or walk) and once time a day.

The diet was given twice a day $(07: 00 \mathrm{~h}$ and 17:00h), and consisted of oat and commercial pellet food in 9:1 ratio $(2 \mathrm{~kg}$ pellet food $/ 100 \mathrm{~kg}$ $\mathrm{bw})$, grass, alfalfa hay and $15 \mathrm{~g}$ of calcium carbonate to each animal. Water and carrots were offered ad libitum.

Samples of heparinized blood were collected from each horse by vein puncture, every $4 \mathrm{~h}$ (03:00h, 07:00h, 11:00h, 15:00h, 19:00h, and 23:00h) during consecutive $48 \mathrm{~h}$. Samples were immediately cooled on ice and then centrifuged. Obtained plasmas were stored at $-20^{\circ} \mathrm{C}$ for further analyses.

Plasma $\mathrm{Na}^{+}, \mathrm{K}^{+}, \mathrm{Ca}^{++}$, and $\mathrm{Mg}^{++}$analyses were done by flame photometry, using acetylene/air flame. Commercial kits were used to determine $\mathrm{Cl}^{-}$levels by ferric tiocianate method ${ }^{1}, \mathrm{Fe}^{++}$ levels by modified Goodwin method ${ }^{2}, \mathrm{P}_{\mathrm{i}}$ levels by phosphomolibdate complex method ${ }^{2}$, glucose and cholesterol levels by Trinder method ${ }^{1}$, triglycerides levels by totally enzymatic method ${ }^{1}$, and total proteins levels by biuret method ${ }^{2}$. UV spectrophotometry was used for reading.

COSINOR method was used for data analysis to determine rhythmical parameters of plasma ions $\left(\mathrm{Ca}^{++}, \mathrm{P}_{\mathrm{i}}, \mathrm{K}^{+}, \mathrm{Na}^{+}, \mathrm{Cl}^{-}, \mathrm{Mg}^{++}, \mathrm{Fe}^{++}\right)$and metabolites levels (glucose, cholesterol, triglycerides, and total proteins), adjusting a $24 \mathrm{~h}$ cosine curve of experimental data (Halberg et al., 1977), with level of significance set at $\mathrm{P} \leq 0.05$. COSINOR analysis was done for each biochemical variable using the data obtained in all seven animals using a $24 \mathrm{~h}$ period to each type of physical activity performed (walk and gallop).

\footnotetext{
${ }^{1}$ Laborlab S/A - Guarulhos, Brazil

${ }^{2}$ Bioclin, Quibasa Química Básica Ltd. - Belo Horizonte, Brazil
} 


\section{RESULTS AND DISCUSSION}

Ions results showed significant diurnal rhythmicity in plasma only regarding Pi levels, when horses performed walk as daily physical activity (Table 1). Its acrophase occurred at early morning (about 05:00 h; Fig. 1). Circadian variations of inorganic phosphorus levels with a maximum peak about 04:00h were already been reported in Standardbred racebred (Lepage et al., 1991) and in humans (Carruthers et al., 1964; Markowitz et al., 1981).

Table 1. Rhythmical parameters of plasma ions and metabolits levels in seven Thoroughbred racehorses when walk and gallop were the physical activity performed

\begin{tabular}{|c|c|c|c|c|c|c|c|c|c|c|}
\hline \multirow{3}{*}{ Variable } & \multicolumn{10}{|c|}{ Exercise performed } \\
\hline & \multicolumn{5}{|c|}{ Walk } & \multicolumn{5}{|c|}{ Gallop } \\
\hline & MESOR & AMP & ACRO (h) & $\% \mathrm{R}$ & PVAL & MESOR & AMP & ACRO (h) & $\% \mathrm{R}$ & PVAL \\
\hline $\mathrm{Ca}^{++}(\mathrm{mEq} / \mathrm{l})$ & $5.65 \pm 0.06$ & 0.22 & $22: 05 \pm 01: 36$ & 12.67 & NS & $5.65 \pm 0.07$ & 0.23 & $22: 00 \pm 01: 36$ & 12.77 & NS \\
\hline$P_{i}(\mathrm{mg} / \mathrm{dl})$ & $3.90 \pm 0.10$ & 0.40 & $05: 38 \pm 01.20$ & 17.49 & $\mathrm{P} \leq 0.05$ & $3.69 \pm 0.07$ & 0.12 & $02: 44 \pm 03.07$ & 3.71 & NS \\
\hline $\mathrm{K}^{+}(\mathrm{mEq} / \mathrm{l})$ & $2.86 \pm 0.07$ & 0.09 & $02: 00 \pm 04: 20$ & 1.95 & NS & $2.85 \pm 0.06$ & 0.10 & $02: 54 \pm 03: 13$ & 3.47 & NS \\
\hline $\mathrm{Na}^{+}(\mathrm{mEq} / \mathrm{l})$ & $156.75 \pm 4.20$ & 1.53 & $12: 44 \pm 14: 49$ & 0.17 & NS & $156.79 \pm 3.82$ & 1.32 & $15: 45 \pm 15: 37$ & 0.15 & NS \\
\hline $\mathrm{Mg}^{++}(\mathrm{mEq} / \mathrm{l})$ & $1.47 \pm 0.02$ & 0.03 & $17: 03 \pm 03: 55$ & 2.37 & NS & $1.48 \pm 0.03$ & 0.04 & $22: 56 \pm 03: 52$ & 2.43 & NS \\
\hline $\mathrm{Cl}^{-}(\mathrm{mEq} / \mathrm{l})$ & $93.12 \pm 1.25$ & 1.10 & $16: 16 \pm 06: 09$ & 0.98 & NS & $90.90 \pm 1.01$ & 2.65 & $00: 25 \pm 02: 04$ & 8.10 & NS \\
\hline $\mathrm{Fe}^{++}(\mu \mathrm{g} / \mathrm{dl})$ & $356.32 \pm 11.33$ & 7.72 & $22: 36 \pm 07: 56$ & 0.59 & NS & $366.10 \pm 13.30$ & 24.52 & $19: 38 \pm 02: 56$ & 4.18 & NS \\
\hline Glucose (mg/dl) & $107.98 \pm 1.43$ & 1.26 & $09: 53 \pm 06: 05$ & 1.00 & NS & $106.76 \pm 1.67$ & 1.87 & $05: 51 \pm 04: 49$ & 1.87 & NS \\
\hline Cholesterol (mg/dl) & $115.52 \pm 1.98$ & 0.78 & $17: 47 \pm 13: 42$ & 0.20 & NS & $115.51 \pm 2.01$ & 0.28 & $12: 32 \pm 14: 28$ & 0.03 & NS \\
\hline Triglycerides $(\mathrm{mg} / \mathrm{dl})$ & $31.65 \pm 1.14$ & 4.28 & $00: 25 \pm 01: 27$ & 15.23 & $\mathrm{P} \leq 0.05$ & $30.10 \pm 1.08$ & 6.89 & $22: 22 \pm 00: 51$ & 34.05 & $\mathrm{P} \leq 0.05$ \\
\hline Total proteins $(\mathrm{g} / \mathrm{dl})$ & $5.36 \pm 0.08$ & 0.12 & $19: 09 \pm 03: 41$ & 2.69 & NS & $5.27 \pm 0.09$ & 0.19 & $23: 59 \pm 02: 27$ & 5.84 & NS \\
\hline
\end{tabular}

MESOR is the mean of cosine curve adjusted to data; AMP is the amplitude; ACRO is the acrophase reported in hours; \% R is the rhythm percent; PVAL is the $\leq 0.05$ probability that the amplitude for 24 h periodicity is zero. NS: not significant ( $\mathrm{P} \geq 0.05$ ).

It is known that serum insulin levels rise shortly after each meal and phosphorus levels fall in response to insulin administration (Soskin et al., 1941). Thus, changes in phosphorus levels are secondary to changes in insulin secretion, which accompany the ingestion of food (Jubiz et al., 1972). Since phosphorus acrophase occurred at early morning, and no food was given at that time, insulin release was not stimulated. So, these acrophase is not influenced by meals (Lepage et al., 1991).

Phosphorus diurnal rhythm was not found when horses performed gallop at early morning (Table 1). This exercise could be masking that rhythm because of the increase of phosphorus losses in feces (Hoyt et al., 1995) and in sweat (Schryver et al., 1978).

In contrast, this diurnal rhythm occurred when horses walked at 16:00 h. Since walk is a low intensity exercise and was performed during the afternoon, Pi losses were insignificant to affect the occurrence of this rhythm.

According to metabolites analyses, only triglycerides showed significant rhythmicity (Table 1). Triglycerides diurnal rhythms were found either when walk or gallop were performed, and acrophases occurred at dark period (Table 1; Fig. 2). Nocturnal acrophase was also described in Thoroughbred racehorses by Viana et al. (2003). Furthermore, Schlierf (1978) found at the same period the highest free fatty acids (FFA) levels, which are the basic constituents of triglycerides.

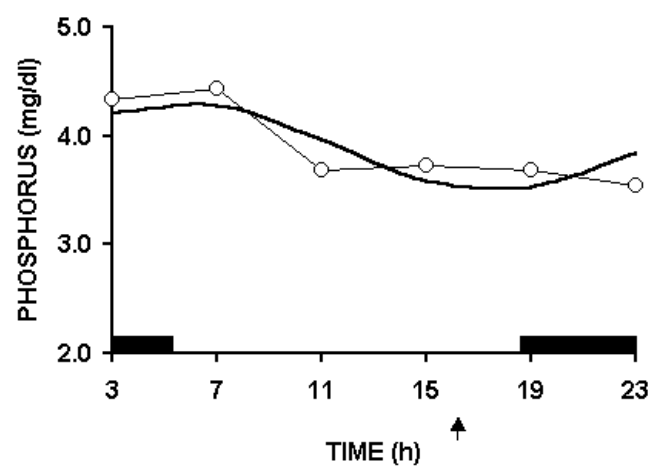

Figure 1. Record of plasma phosphorus levels in Thoroughbred racehorses when walk was the physical activity performed. Dotted curve (०-०) represents mean plasma phosphorus levels, continuous curve $(-)$ the values obtained by COSINOR method $(\mathrm{P} \leq 0.05), \uparrow$ time of physical activity (walk), $\square$ light period, and $\mathbf{\square}$ dark period. 

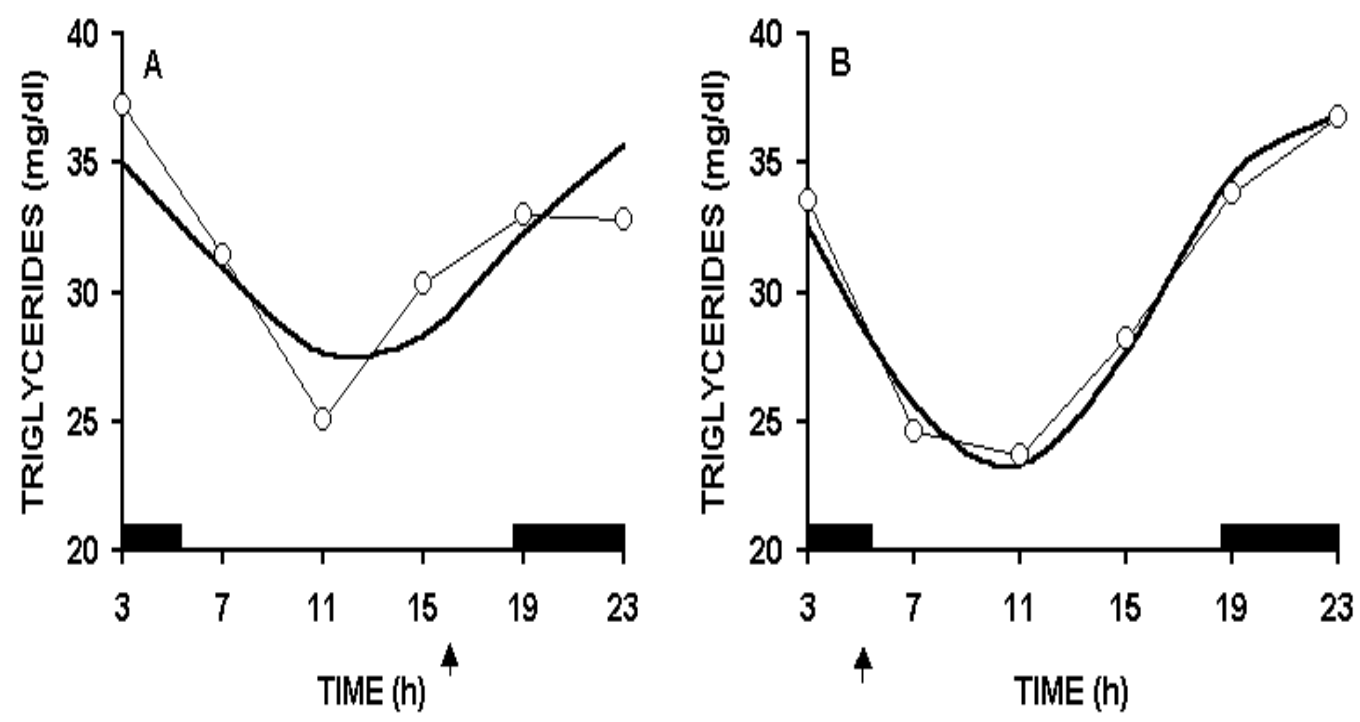

Figure 2. Record of plasma triglycerides levels in Thoroughbred racehorses when walk (panel A) and gallop (panel B) were the physical activities performed. Dotted curve $\left(\mathrm{o}_{-} \mathrm{o}\right)$ represents mean plasma triglycerides levels, continuous curve $(-)$ the values obtained by COSINOR method (P $\leq 0.05), \uparrow$ time of physical activity (walk or gallop), $\square$ light period, and $\mathbf{\square}$ dark period.

Its significant MESOR were higher than reference limits $(3.4-4.6 \mathrm{mg} / \mathrm{dl})$ reported by Ricketts (1987). However, this MESOR was inside normality limits described by Viana et al. (2003), who studied plasma triglycerides over a 72h-period.

A decrease in gallop cosine curve amplitude can be noticed when it is compared to walk cosine curve amplitude. This decline, mainly in batifase (period when it reachs the lowest level) could be the result of a greater utilization of triglycerides during high intensity exercise (Miller-Graber et al., 1991; Perez et al., 1997), suggesting that training enhances the extraction and efficiency of oxidation of plasma free fatty acids (FFA) by muscle (Koivisto et al., 1982). Snow et al. (1983) reported that during maximal exercise in horses, the FFA levels decrease while glycerol increase, which suggest utilization of FFA. This mobilization is enhanced by catecholemines, glucagons (Miller-Graber et al., 1991; Lawrence et al., 1993), cortisol (Jeffcott and Field, 1985) and a decrease of insulin effectiveness (Lawrence et al., 1993).

Since this rhythm was also described in Thoroughbred racehorses at same nocturnal acrophase (Viana et al., 2003), physical training (walk and gallop) was not influencing triglycerides diurnal rhythms occurrence. In this case, gallop was just decreasing its amplitude.

Diurnal rhythms of plasma potassium were not observed either when walk or gallop was performed. However, potassium rhythm was reported in athlete Thoroughbred racehorse, with nocturnal acrophase (Viana et al., 2003).

Furthermore, it was not observed the presence of diurnal rhythms in plasma calcium, sodium, chloride, magnesium, iron, glucose, cholesterol and total protein levels. These diurnal rhythms in Thoroughbred racehorse, under physical training, were also not found by Viana et al., (2003). Thus, these results could be attributed to be a lack of rhythmicity and/or synchrony.

This study demonstrated that high intensity exercise (gallop) had a masking effect on phosphorus diurnal rhythm. Besides, triglycerides diurnal rhythm was not influenced by physical training. The effect of gallop in triglycerides diurnal rhythm was just a decline in its amplitude.

\section{ACKOWLEDGEMENTS}

The authors are very grateful to Dr. Pedro Henrique Monnerat and Mr José Accácio Silva for teaching the flame photometry technique. 
The valuable contribuition in technical assistance given by Miss Patrícia Dias is also gratefully acknowledged. This project was supported by FENORTE and FAPERJ.

\section{REFERENCES}

CARRUTHERS, B.M.; COPP, D.H.; MCINTOSH, H.W. et al. Diurnal variation in urinary excretion of calcium and phosphate and its relation to blood levels. J. Lab. Clin. Med., v.63, p.959-968, 1964.

CIPOLLA-NETO, J. Aplicações médicas da cronobiologia. In: CIPOLLA-NETO, J.; MARQUES, N.; MENNA-BARRETO, L.S. (Eds). Introdução ao estudo da cronobiologia, São Paulo: ÍCONE, 1988. p.157-198.

HALBERG, G.; CARANDENTE, F.; CORNÉLISSEN, G. et al. Glossary of chronobiology. Chronobiologia, v.4, p.1-189, 1977.

HOYT, J.K.; POTTER, G. D.; GREENE, L.W. et al. Mineral balance in resting and exercised miniature horses. J. Equine Vet. Sci., v.15, p.310314, 1995.

JEFFCOTT, L.B.; FIELD, J.R. Current concepts of hyperlipaemia in horses and ponies. Vet. Rec., v.116, p.461-466, 1985.

JUBIZ, W.; CANTERBURY, J.M.; REISS, E. et al. Circadian rhythm in serum parathyroid hormone concentration in human subjects: Correlation with serum calcium, phosphate, albumin, and growth hormone levels. J. Clin. Invest., v.51, p.2040-2046, 1972.

KOIVISTO, V.; HENDLER, R.; NADEL, E. et al. Influence of physical training on the fuelhormone response to prolonged low intensity exercise. Metabolism, v.31, p.192-197, 1982.

LAWRENCE, L.; SODERHOLM, V.L.; ROBERTS, A. et al. Feeding status affects glucose metabolism in exercising horses. $J$. Nutr., v.123, p.2152-2157, 1993.

LEPAGE, O.M.; DESCÔTEAUX, L.; MARCOUX, M. et al. Circadian rhythms of osteocalcin in equine serum. Correlation with alkaline phosphatase, calcium, phosphate and total protein levels. Can. J. Vet. Res., v.55, p.510, 1991.
MARKOWITZ, M.E.; ROTKIN, L.; ROSEN, J.F. Circadian rhythms of blood minerals in humans. Science, v.213, p.672-674, 1981.

MILLER-GRABER, P.A.; LAWRENCE, L.M.; FOREMAN, J.H. et al. Dietary protein level and energy metabolism during treadmill exercise in horses. J. Nutr., v.121, p.1462-1469, 1991.

NOGUEIRA, G.P.; BARNABE, R.C.; BEDRAN-DE-CASTRO, J.C. et al. Serum cortisol, lactate and creatine concentrations in Thoroughbred fillies of differents ages and states of training. Braz. J. Vet. Res. Anim. Sci., v.39, p.54-57, 2002.

PEREZ, R.; GARCIA, M.; CABEZAS, I. et al. Physical activity, cardiovascular and biochemical changes of chilean purebred horses to rodeo competitions. Arch. Med. Vet., v.29, p.221-234, 1997.

RICKETTS, S.W. The laboratory as an aid to clinical diagnosis. Vet. Clin. N. Am.: Equine Pract., v.3, p.445-460, 1987.

ROSE, R.J.; HODGSON, D.R.; EVANS, D. Research in equine exercise physiologist at the University of Sydney. J. Equine Vet. Sci., v.18, p.86-90, 1998.

SCHLIERF, G. Diurnal variations in plasma substrate concentration. Eur. J. Clin. Invest., v.8, p.59-60, 1978.

SCHRYVER, H. F.; HINTZ, H. F.; LOWE, J.E. Calcium metabolism, body composition and sweat losses of exercised horses. Am. J. Vet. Res., v.39, p.245-248, 1978.

SNOW, D.H.; FIXTER L.M.; KERR, M.G. et al. Alterations in composition of venous plasma FFA pool during prolonged and sprint exercises in the horse. In: KNUTTGEN, E. G.; VOGEL, J. A.; POORTMANS, J. (Eds). The biochemistry of exercise. Champagne-Illinois: Human Kinetics, 1983. v.13, p.336-350.

SOSKIN, S.; LEVINE, R.; HECHTER, D. The relation between the phosphate changes in blood and muscles following dextrose, insulin and epinephrine administration. Am. J. Physiol., v.134, p.40, 1941.

VIANA, P.C.R.; CALDAS-BUSSIERE, M.C.; MARINS, R. S. Q. S. et al. Diurnal rhythms of plasma ions and metabolites levels in Thoroughbred racehorses. Biol. Rhythm Res., v.34, p.347-354, 2003. 